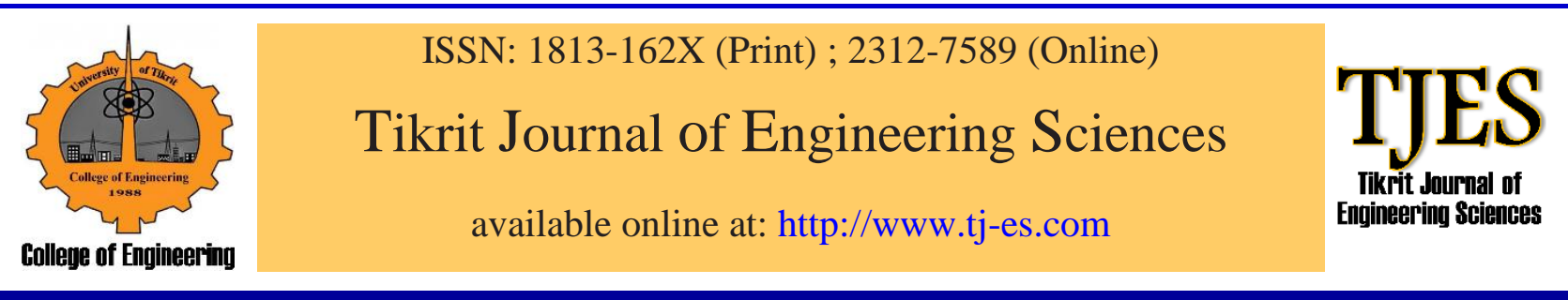

\section{Hanadi Sibai * \\ Huda Alrifaie \\ Food Engineering Department \\ Faculty of Petroleum and Chemical \\ Engineering \\ Al-Baath University \\ Homs, Syria}

\title{
The Effect of Frying Conditions on Sunflower Oil Attributes
}

\author{
A B S T R A C T
}

A sample of sunflower oil, produced from Homs Sugar Company, was used in this study to fry local potato by frying under air at household conditions, and frying under pressure (at $150-180^{\circ} \mathrm{C}$, pressure $10-15 \mathrm{~kg} / \mathrm{cm}^{2}$ ) for 12 continuous hours without adding new oil. The results were estimated statistically by using Minitab program version 17.0 at level 0.01 . The results showed, in both cases of frying, an increase in the physical properties (density, viscosity, refractive index, and coloring degree) of used oil by increasing frying time. A decrease Iodine Number, increase Peroxide Number, increase the percentage of free fatty acids, increase of $\mathrm{C}_{16: 0}$ and $\mathrm{C}_{18: 1}$ acids percentage, and decrease of $\mathrm{C}_{18: 2}$ and $\mathrm{C}_{18: 3}$ acids percentage, associated by increasing frying time. But when frying under pressure we noticed that these changes were slow because of the unadequated oxygen presence during frying under pressure. So we can say that the oil was still usable for frying for a long time when frying under pressure more than when frying under air with the vessel is

(c) 2018 TJES, College of Engineering, Tikrit University

Received 16 October 2017

Accepted 27 May 2018

Available online 17 June 2018 open.

5130/tjes.25.2.07
تأثير ظروف القلي على خصائص زيت عباد الثمس

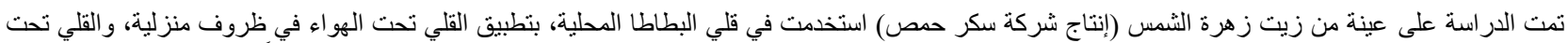

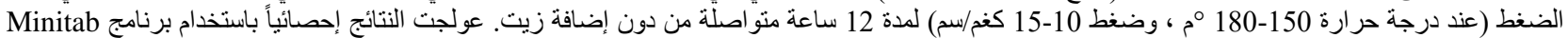

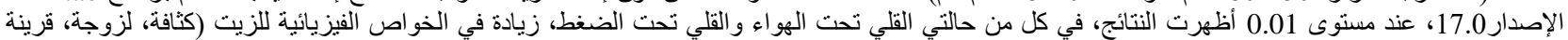

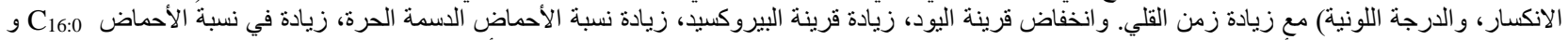

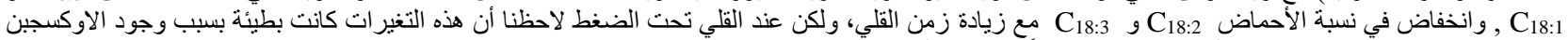
بنسبة غير كافية. وبذللك يمكننا القول بأن الزيت بقي صالحاً للقلي لمدة أطول عند القلي تحت الضغط مقارنة مع القلي تحت الهواء والإناء مفتوح.

\section{INTRODUCTION}

Frying process is defined as food immersion in hot oil with contact between oil, food, and air at high temperature 150-190 ${ }^{\circ} \mathrm{C}$. Synchronization heat, oil transmission, foodstuff, and air during frying process produce unique desirable fried foods, also frying oil act as heat transfer contribute the frying food texture and flavor. Frying temperature and humidity of foodstuff affect the properties of oil and fat using in frying process that lead up to decrease its quality and change its chemical composition, this is related with frying time and chemical composition of used oil, because frying process decrease the unsaturation of fatty acids in oil by increasing polymerization, and increase foam, density, viscosity, coloring degree of used oil, also its content of free fatty acids, functional materials, and polymeric compounds [1].

During frying process set of chemical reactions occur to used oil, one of them is oil hydrolysis. As foods fried in hot oil, a vapor is formed because of moisture that evaporated with bubbles then decrease gradually during frying. Water, vapor, and oxygen are lead the chemical reactions in food and frying oil to begin. Water and weak nucleophyl attack the ester bond in tri-acid acyl glycerol and produce mono and diacyl glycerol, glycerol, and free fatty acids [2,3].

Large amounts of water hydrolyze the oil rapidly, and water hydrolyzes the oil faster than steam, and the large 
contact between the oil and the aqueous phase of food increases hydrolysis of oil [4-6].

The chemical mechanization of thermal oxidation is similar to autoxidation mechanism, but thermal oxidation average is faster than autoxidation. Thermal oxidation includes three stages, which are: initiation, propagation, and termination, illustrated in Fig. 1 [7,3]. Oil should be in a radical state to react with radical oxygen for oil oxidation reaction, the hydrogen with the weakest bond on the carbon of oil will be removed first to become radical [8-10].

Oxidation hydrolysis reactions range is increased when hydrogen and free radicals concentration increase. The amount of mono and diacyl glycerol at the beginning of frying process is little. And because of high surface tension in frying system, the vapor bubbles will break and a layer of vapor formed at oil surface which lower the rubbing between oil and oxygen so the oil oxidation will be decreased $[11,12]$.

The chemical reactions that occur during the oxidation process contribute to the formation of both volatile and nonvolatile decomposition products, the volatile degradation products are usually saturated and monounsaturated hydroxyl, aldehydic, keto, and dicarboxylic acids; hydrocarbons; alcohols; aldehydes; ketones; and aromatic compounds are primarily responsible for undesirable oxidized (rancid) flavors, so, we can say that the autoxidation is an important degradation reaction which is attributed to the rancidity of oil and fat. Thermal oxidation, which is accelerated at the high temperature used in deep frying, creats rancid flavors and reduces the organoleptic characteristics of fried food [13-15]. The hydroperoxides are not generally stable during the deep-fat frying, they are decomposed to alkoxy radicals and hydroxyl radicals by homolysis of the peroxide bond [16].

Volatile compounds in frying oil suffer another reaction such as oxidation, dimerization, and polymerization. Volatile compounds also support the frying oil flavor quality, and consequently the fried foods. Many nonvolatile polar compounds and tri-acylglycerol dimmers and polymers are produced in thermal oxidized oil by radical reactions. Dimerization and polymerization are major reactions in the thermal oxidation in oil $[17,18]$.

Polymerization occurs more easily in oil with high linoleic acid than in high oleic acid oil contents. As polymerized products increase in the frying oil, viscosity of the oil and undesirable color of food also increases. During frying, oils with polyunsaturated fatty acids, such as linoleic acid, have a distinct induction period of hydroperoxides followed by a rapid increase in peroxide values, then a rapid destruction of peroxides [19,20].

Sunflower oil is considered as one of the best oils used in frying because of its low smoking point, slight color and taste, low level of saturated fats found in, and its firmness at high cooking degrees, also, it is an excellent oil for household using such as backing preparing, frying, and salads. Foodstuff frying by using vegetable oils is done in open vessels contacted with air as for household frying, or under pressure by using closed household frying devices, small and large, for restaurants and factories [21-23].

This research is aimed to study the effect of frying time on physical and chemical sunflower oil attributes while potato frying without adding new oil throughout frying, and frying is done in contact with air and under pressure in an electric frying pan, and determine the period can use this oil in frying with keeping its quality.

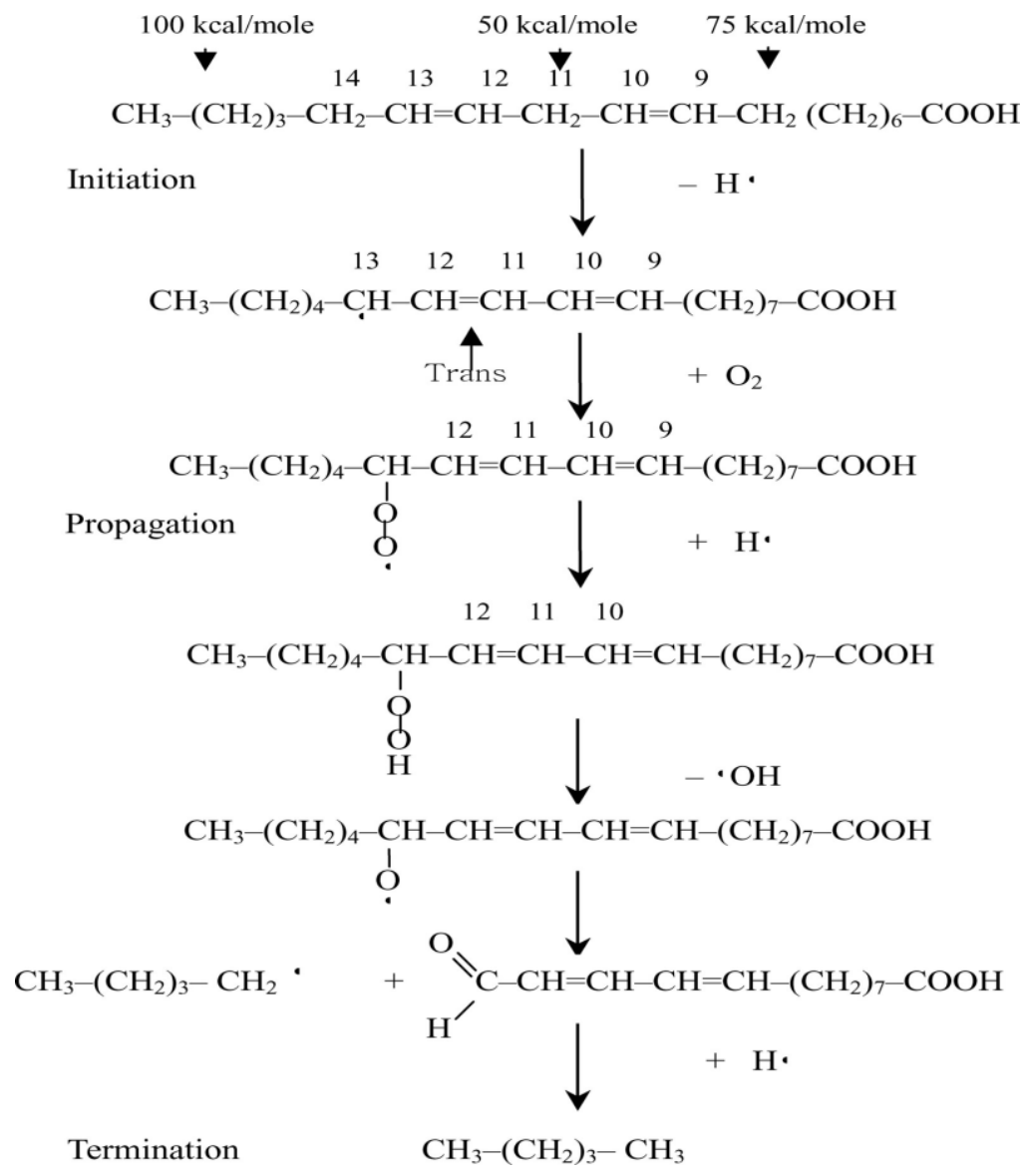

Fig. 1. The initiation, propagation, and termination of thermal oxidation of oil [3]. 


\section{MATERIAL AND METHODS 2.1. Materials}

Sunflower oil produced from Homs Sugar Company, was used in frying local potato in household conditions in an open vessel for frying under air, and for frying under pressure we used a tightly closed electric frying pan under pressure $15 \mathrm{~kg} / \mathrm{cm}^{2}$, and temperature about $180{ }^{\circ} \mathrm{C}$. The electric pan depth wasn't large, so the height of added oil was enough to let a little space between surface oil and pan cover, in this way we reduced the amount of air, and thus, oxygen as possible as we could. The frying process was continued for 12 hours without adding new oil.

\subsection{Methods}

\section{Physical Tests}

Density, viscosity, refractive index, and coloring degree for used oil were measured before and during frying. Density $\left(\mathrm{g} / \mathrm{cm}^{3}\right)$ was measured at $20{ }^{\circ} \mathrm{C}$ by using density flask according to AOAC (1990) [24], viscosity (Poise) is measured according to Stocks Method, refractive index was measured by refractometer at $20{ }^{\circ} \mathrm{C}$, and coloring degree was measured by using Lyvipond colorometer.

\section{Chemical Tests}

Iodine number, peroxide value, and percent of free fatty acids were measured for used oil before and during frying. Iodine number indicates the iodine grams that absorbed by $100 \mathrm{gr}$ of oil, ( $\mathrm{g} \mathrm{I}_{2} / 100 \mathrm{gr}$ Oil). Peroxide number was evaluated as ( $\mathrm{ml}$ eq. peroxide $/ 1 \mathrm{~kg}$ Oil). While free fatty acids were calculated as a percentage on account of oleic acid.

\section{Chromatographical Test}

The used oil was tested before and at the end of frying process by using Gas Chromatogrphy, that for qualitative and quantitative tests of fatty acids found in glycerides forming the test sample. The apparatus is of the model Shimadzu 1998, supplied with injection system (spilt/splitless), with gas insert, flame ioned detector FID, hydrogen generation device (Shimadzu-OPGU-2200S), air pump, nitrogen gas from nitrogen generation device (Peakseries, 600A), capillary column of trademark Teknokorma was used, Spanish origin, have the symbol TR-140533 and sequential number 2056295, column length 30 meter and with diameter $0.32 \mathrm{~mm}$, painted with stable phase of kind TRB-WAX. Work conditions was controlled as follows: column temp. $195{ }^{\circ} \mathrm{C}$, injection temp. $250{ }^{\circ} \mathrm{C}$, detector temp. $250{ }^{\circ} \mathrm{C}$, holder gas flow 0.7 , and partition percent $10: 1$.

\section{RESULTS AND DISCUSSION 3.1. Frying Under Air}

Physical properties of oil samples taken during frying process under air, presented in Table 1, showed an increase of density, viscosity, and refractive index. This is because of the thermal oxidation of oil having unsaturated fatty acids and accumulation of high molecular weight compounds and polymerization occurrence, the results we found were agreed with what was found by Marmesat et al. [22] and Hasson [25]. As for coloring degree, it was increased as frying time increased, because of polymerization and forming the free radicals as a result of thermal oxidation which oxidize the pigments found in oil, also from transmission food pigments into frying oil, this increase in coloring degree was agreed with what was found by Melton et al. [26] and Yunsheng [27]

From chemical analysis of oil samples taken during frying process under air, shown in Table 2, we noticed decreasing of iodine number, and increasing of peroxide number and percent of free fatty acids accomplished by increasing frying time. This is because of glycerides hydrolysis and thermal oxidation which lead to accumulation of free fatty acids, breaking down the double bonds of unsaturated fatty acids, and forming free radicals that produce peroxides and hydroperoxides. As for peroxide number, after increasing, it decreases because of the dissociation of peroxides and hydroperoxides to ketones and aldehydes. The results we found were similar to what was found by Farag et al. [28], Bangash and Khattak [29], Farhoosh and Moosovi [30]. Statistically, significant differences were found at level 0.01 .

Table 1

Physical properties of oil samples before and during potato frying under air.

\begin{tabular}{|c|c|c|c|c|c|}
\hline \multirow{2}{*}{$\begin{array}{l}\text { Frying Time } \\
\text { (hour) }\end{array}$} & \multirow{2}{*}{$\begin{array}{l}\text { Density } \\
\text { at } 20^{\circ} \mathrm{C}\left(\mathrm{g} / \mathrm{cm}^{3}\right)\end{array}$} & \multirow{2}{*}{$\begin{array}{l}\text { Viscosity } \\
\text { at } 20^{\circ} \mathrm{C} \text { (Poise) }\end{array}$} & \multirow{2}{*}{$\begin{array}{l}\text { Refractive index } \\
\text { at } 20^{\circ} \mathrm{C}\end{array}$} & \multicolumn{2}{|c|}{$\begin{array}{l}\text { Coloring degree } \\
\text { (Lyvipond) }\end{array}$} \\
\hline & & & & Red & Yellow \\
\hline Before frying & ${ }^{\mathrm{D}} 0.9180$ & $\mathrm{G}_{3.4862}$ & A 1.4748 & ${ }^{\mathrm{A}} 0.6$ & A 4 \\
\hline 2 & ${ }^{\mathrm{CD}} 0.9184$ & $F_{3} .7352$ & A 1.4750 & A 0.6 & A 4 \\
\hline 4 & ${ }^{\mathrm{C}} 0.9187$ & $\mathrm{E}_{4} .1086$ & A 1.4751 & A 0.7 & A 4 \\
\hline 6 & ${ }^{\mathrm{BC}} 0.9190$ & $\mathrm{D}_{4} .3574$ & A 1.4752 & ${ }^{\mathrm{A}} 0.7$ & A 5 \\
\hline 8 & ${ }^{\mathrm{AB}} 0.9194$ & $\mathrm{c}_{4} .6063$ & A 1.4754 & A 0.7 & A 5 \\
\hline 10 & ${ }^{\mathrm{AB}} 0.9196$ & B 4.7307 & A 1.4755 & A 0.7 & A 5 \\
\hline 12 & A 0.9199 & A4.9796 & A 1.4757 & A 0.7 & A 5 \\
\hline
\end{tabular}

*Duplicate tests were done for everyone of studied samples

*Different letters in the same column indicate presence of significant differences at level 0.01 
Table 2

Chemical analysis of oil samples before and during potato frying under air.

\begin{tabular}{|c|c|c|c|}
\hline $\begin{array}{l}\text { Frying Time } \\
\text { (hour) }\end{array}$ & $\begin{array}{l}\text { Iodine number } \\
\text { (g I } / 100 \mathrm{~g} \text { oil) }\end{array}$ & $\begin{array}{l}\text { Peroxide number } \\
\text { (ml eq.peroxide/1 kg oil) }\end{array}$ & $\begin{array}{l}\text { Free fatty acids } \\
(\%)\end{array}$ \\
\hline Before frying & $\mathrm{A} 127.4$ & ${ }^{\mathrm{G}} 0.98$ & ${ }^{\mathrm{D}} 0.0705$ \\
\hline 2 & B 121.7 & ${ }^{\mathrm{F}} 6.37$ & ${ }^{\mathrm{D}} 0.0705$ \\
\hline 4 & B 119.7 & ${ }^{\mathrm{E}} 15.98$ & ${ }^{\mathrm{D}} 0.0705$ \\
\hline 6 & ${ }^{\mathrm{BC}} 117.9$ & D34.16 & ${ }^{\mathrm{D}} 0.0705$ \\
\hline 8 & ${ }^{C D} 115.5$ & ${ }^{C_{2}} 23.91$ & ${ }^{\mathrm{C}} 0.0846$ \\
\hline 10 & ${ }^{\mathrm{DE}} 113.4$ & B 45.98 & ${ }^{\mathrm{A}} 0.1410$ \\
\hline 12 & ${ }^{\mathrm{E}} 110.0$ & ${ }^{\mathrm{A}} 67.00$ & ${ }^{\mathrm{B}} 0.1551$ \\
\hline
\end{tabular}

\subsection{Frying Under Pressure}

From physical properties of oil samples taken during frying process under pressure, shown in Table 3, we noticed an increase of density, viscosity, and refractive index because of the high frying temperature which lead to polymerization occurrence and oil oxidation that cause to accumulate free fatty acids, mono, and diacylglycerols. The results we found were correspondent to what was found by Yan [31], Tseng et al. [32]. Also we found an increase of coloring degree accomplished by increasing frying time because of thermal oxidation of oil, breaking down the pigments found in oil by high frying temperature, and pigments transmission from food to oil. This result was similar to what was found by Smouse [33] and Verela et al. [34].

Table 3

Physical properties of oil samples before and during potato frying under pressure.

\begin{tabular}{|c|c|c|c|c|c|}
\hline \multirow{2}{*}{$\begin{array}{l}\text { Frying Time } \\
\text { (hour) }\end{array}$} & \multirow{2}{*}{$\begin{array}{l}\text { Density } \\
\text { at } 20^{\circ} \mathrm{C}\left(\mathrm{g} / \mathrm{cm}^{3}\right)\end{array}$} & \multirow{2}{*}{$\begin{array}{l}\text { Viscosity } \\
\text { at } 20^{\circ} \mathrm{C} \text { (Poise) }\end{array}$} & \multirow{2}{*}{$\begin{array}{l}\text { Refractive index } \\
\text { at } 20^{\circ} \mathrm{C}\end{array}$} & \multicolumn{2}{|c|}{$\begin{array}{l}\text { Coloring degree } \\
\text { (Lyvipond) }\end{array}$} \\
\hline & & & & Red & Yellow \\
\hline Before frying & ${ }^{\mathrm{D}} 0.9152$ & $\mathrm{~A}_{3.1180}$ & A 1.4749 & ${ }^{\mathrm{A}} 0.6$ & B 3 \\
\hline 2 & ${ }^{\mathrm{CD}} 0.9158$ & B 3.2595 & A 1.4745 & ${ }^{\mathrm{A}} 0.6$ & B 3 \\
\hline 4 & ${ }^{c} 0.9166$ & $\mathrm{C}_{3.4011}$ & А 1.4742 & ${ }^{\mathrm{A}} 0.7$ & $\mathrm{AB} 4$ \\
\hline 6 & ${ }^{\mathrm{B}} 0.9192$ & D3.5422 & A 1.4741 & ${ }^{\mathrm{A}} 0.7$ & $\mathrm{AB} 4$ \\
\hline 8 & ${ }^{\mathrm{A}} 0.9204$ & E3.8253 & A 1.4739 & A 0.7 & $\mathrm{AB} 4$ \\
\hline 10 & ${ }^{\mathrm{AB}} 0.9197$ & F3.9665 & A 1.4736 & ${ }^{\mathrm{A}} 0.8$ & A 5 \\
\hline 12 & ${ }^{\mathrm{AB}} 0.9197$ & $\mathrm{G}_{4} .1085$ & A 1.4733 & ${ }^{\mathrm{A}} 0.8$ & A 5 \\
\hline
\end{tabular}

*Duplicate tests were done for everyone of studied samples

*Different letters in the same column indicate presence of significant differences at level 0.01 .

Table 4

Chemical analysis of oil samples before and during potato frying under pressure.

\begin{tabular}{|c|c|c|c|}
\hline $\begin{array}{l}\text { Frying Time } \\
\text { (hour) }\end{array}$ & $\begin{array}{l}\text { Iodine number } \\
\text { (g I } / 100 \mathrm{~g} \text { oil) }\end{array}$ & $\begin{array}{l}\text { Peroxide number } \\
\text { (ml eq.peroxide/1kg oil) }\end{array}$ & $\begin{array}{l}\text { Free fatty acids } \\
(\%)\end{array}$ \\
\hline Before frying & ${ }^{\mathrm{A}} 129.7$ & ${ }^{\mathrm{C}} 0.77$ & ${ }^{\mathrm{D}} 0.1692$ \\
\hline 2 & ${ }^{\mathrm{B}} 122.4$ & ${ }^{\mathrm{B} C} 0.98$ & ${ }^{\mathrm{D}} 0.1833$ \\
\hline 4 & ${ }^{\mathrm{C}} 116.4$ & B 1.08 & ${ }^{\mathrm{D}} 0.1974$ \\
\hline 6 & ${ }^{\mathrm{D}} 112.5$ & $\mathrm{AB} 1.26$ & ${ }^{\mathrm{D}} 0.2256$ \\
\hline 8 & ${ }^{\mathrm{E}} 108.2$ & ${ }^{\mathrm{A}} 1.44$ & ${ }^{\mathrm{C}} 0.3948$ \\
\hline 10 & ${ }^{\mathrm{EF}} 105.3$ & $\mathrm{AB} 1.15$ & ${ }^{\mathrm{B}} 0.5358$ \\
\hline 12 & $\mathrm{~F}_{1} 103.7$ & $\mathrm{~A} 1.39$ & $\mathrm{~A} 1.2690$ \\
\hline
\end{tabular}

*Duplicate tests were done for everyone of studied samples.

*Different letters in the same column indicate presence of significant differences at level 0.01 . 


\subsection{Chromatographical Test}

When compared chromatographical test results for used oil, before and at the end of frying time, when frying under air and under pressure, which illustrated in Figs. 2-5, respectively, we noticed an increase of $C_{16: 0}$ and $C_{18: 1}$ acids percentage, and decrease of $\mathrm{C}_{18: 2}$ and $\mathrm{C}_{18: 3}$ acids percentage at the end of frying time. The decrease in unsaturated fatty acids percentage was accomplished by iodine number decrease, and it was because of the oxidation of double bonds found in unsaturated fatty acids by high frying temperature. This result was similar to was found by Orthoefer and Cooper [36] and Suliman et al. [37].

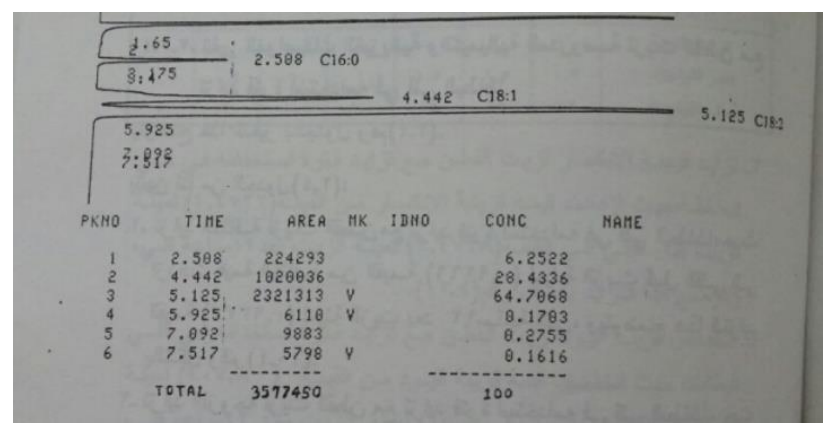

Fig. 2. Chromatogram of sunflower oil sample before frying under air.

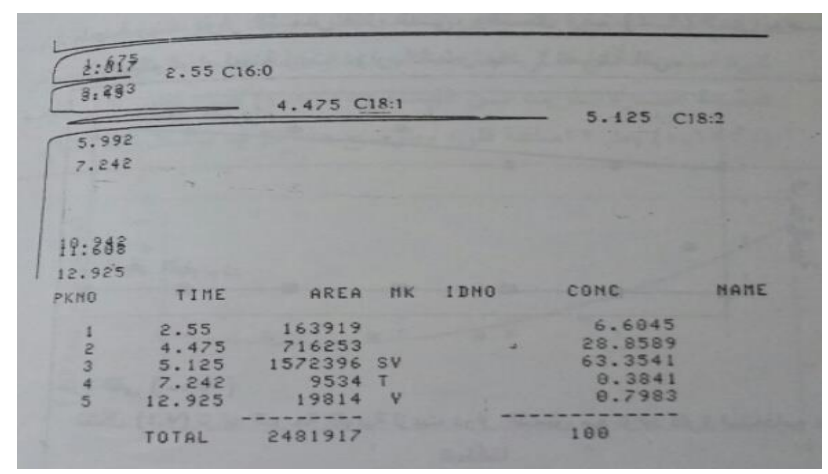

Fig. 3. Chromatogram of sunflower oil sample after 12 hours of frying under air.

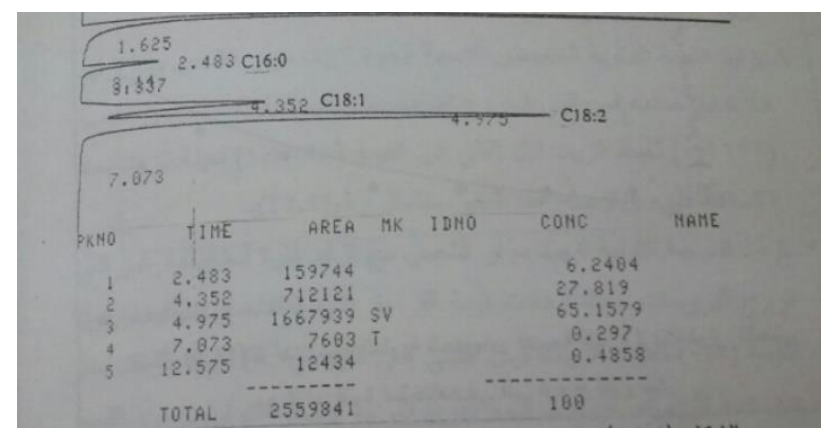

Fig. 4. Chromatogram of sunflower oil sample before frying under pressure.

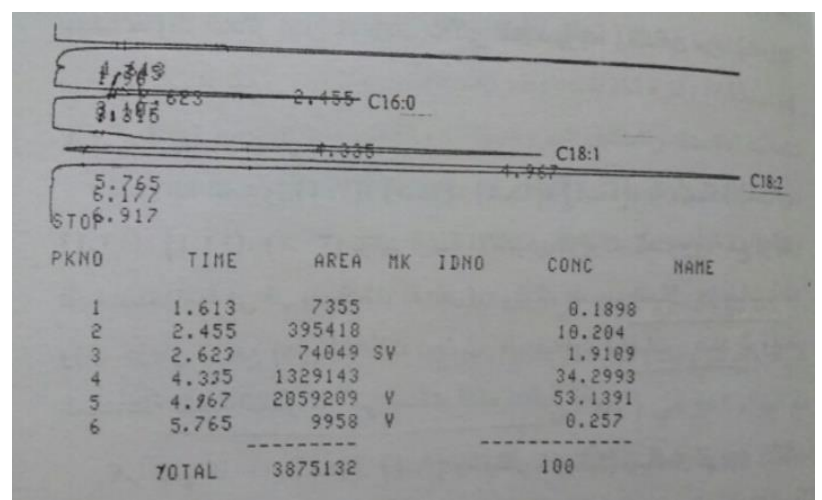

Fig. 5. Chromatogram of sunflower oil sample after 12 hours of frying under pressure.

\section{CONCLUSIONS}

Increase sunflower oil density, viscosity, and refractive index while increase frying time, in both frying cases, (frying under air and frying under pressure), is because of the high frying temperature that lead to polymerization and thermal oxidation of oil having unsaturated fatty acids that increase mono, diacylglycerols, and free fatty acids. Also increasing frying time lead to increase coloring degree of frying oil because of thermal oxidation, polymerization, breaking down the pigments found in oil, and transmission of food pigments to frying oil. As for chemical analysis, during frying process under air and under pressure, we found decreasing of iodine number, increasing of peroxide number, and percent of free fatty acids accomplished by increasing frying time. This is because of glycerides hydrolysis and thermal oxidation which lead to accumulation of free fatty acids, breaking down the double bonds of unsaturated fatty acids, and forming free radicals that produce peroxides and hydroperoxides. As for peroxide number, after increasing, it decreases because of the dissociation of peroxides and hydroperoxides to ketones and aldehydes. But, in case of frying under pressure, we noticed that these changes were slow because of the inadequate oxygen presence during frying under pressure. Also we found, in both cases of frying, increase of $\mathrm{C}_{16: 0}$ and $\mathrm{C}_{18: 1}$ acids percentage, and decrease of $\mathrm{C}_{18: 2}$ and $\mathrm{C}_{18: 3}$ acids percentage at the end of frying time. The decrease in unsaturated fatty acids percentage was accomplished by iodine number decrease, and it was because of the oxidation of double bonds found in unsaturated fatty acids by high frying temperature. The results we found were similar to many researches were done in this scale of study.

\section{REFERENCES}

[1] Orthoefer FT. Care of food service frying oils. Journal of the American Oil Chemists' Society 1988; 65 (9): 1417-1419.

[2] Chung J, Lee J, Choe E. Oxidative stability of soybean and sesame oil mixture during frying of flour dough. Journal of Food Science 2004; 69: 574-578.

[3] Chloe, E. and Min, D.B. Chemistry of deep -fat frying oils. Journal of Food Science 2007; 72:77-82

[4] Blumenthal, M. M. A new look at the chemistry and physics of deep fat frying. Food Technology 1991; 45 :68-71. 
[5] María DJ, Cibele CO, María EA, Norma SW, Lireny AG. Degradation in soybean oil, sunflower oil and partially hydrogenated fats after food frying, monitored by conventional and unconventional methods. Food Control 2011; 22 (12):1920-1927.

[6] Erickson DR. Production and composition of frying fats, Journal of the American Oil Chemists' Society 2006; 75: 563-568.

[7] Proyer WA. Free radical reactions and their importance in Biochemical systems. Federation Proceedings 1973; 32:1862

[8] Masson L, Robert P, Izaurieta M. Fat deterioration in deep fat frying of French fries potatoes at restaurant and food shop sector. Grasasy Aceites 1999; 50: 460.

[9] Innawong B, Mallikarjunan P, Irundayaraj J, Marcy JE. The determination of frying oil quality using Fourier transform infrared attenuated total reflectance. Lebensmittel-Wissenschaft undTechnologie 2004; 37: 23-28.

[10] Sánchez-Muniz FJ, Bastida S, Márquez-Ruiz G, Dobarganes C, Effect of heating and frying on oil and food fatty acids. Fatty Acid in food and Their Health, Taylor \& Francis Group. NW. Boca Raton, F; 2008: pp.511-535.

[11] Dobarganes, CM, Márquez-Ruiz G, Formation and analysis of oxidized monomeric, dimeric and higher oligomeric triglycerides. In: Deep Frying: Chemistry, Nutrition and Practical Applications - 2nd ed., AOCS Press, Champaign; 2007: pp.87-110

[12] Peers KE, Swoboda AT, Deterioration of sunflower seed oil under simulated frying conditions and during small-scale frying of potato chips. Journal of the Science of Food and Agriculture 1982: 383- 389.

[13] Shahidi F, Wanasundara UN. Methods for measuring oxidative rancidity in fats and oils. In C. C. Akoh \& D. B.Min (Eds.), Food lipids: Chemistry, nutrition, and biotechnology (2nd Ed). New York: MarcelDekker, Inc: 2002; pp. 465-482

[14] Warner K. Chemistry of frying oils. Food lipids. 2nd ed. New York: Marcel Dekker Inc. 2002.

[15] Omer AMN, El Mugdad AA, Mariod AA, Mokhtar MM. Chemical reactions taken place during deep-fat frying and their products: A review. Journal of Natural and Medical Sciences 2014.

[16] Nawar WW. Chemical changes in lipids produced by thermal processing. Journal of Chemical Education 1984; 61: 299-302.

[17] Gupta MK. Oil quality improvement through processing. introduction to fat and oil technology. 2nd ed., American Oil chemistry, Society publication, Peoria, IL; 2000.

[18] Farhoosh R, Hossein M, Tavassoli K. Simultaneous monitoring of the conventional qualitative indicators during frying of sunflower oil. Food Chemistry 2011; 125 (1): 209-213.

[19] Choe E, Min DB. Mechanisms and factors for edible oil oxidation. Review Food Science Food Safety 2006; 5: 169-186.

[20] Choe EA, Min DB. Mechanisms of antioxidants in the oxidation of foods: Comprehensive reviews. Journal of Food Science and Food Safety 2009; 8 :345-358.

[21] Romero A, Sánchez-Muniz FJ, Cuesta C. Deep fat frying of frozen foods in sunflower oil. Fatty acid composition in fryer oil and frozen pre-fried potatoes. Journal of the Science of Food and Agriculture 2000; 80: 2135.

[22] Marmesat S, Rodrigues E, Velasco J, Dobarganes MC. Quality of used frying fats and oils: comparison of rapid tests based on chemical and physical oil properties. International Journal of Food Science \& Technology 2007; 42: 601-608.

[23] María JC, Verónica S, Mónica C, Laura O, Marina T. Changes produced in oils during vacuum and traditional frying of potato chips. Food Chemistry 2014; 146 (1): 603-607.

[24] AOAC. Official methods of analysis. 15th ed., Association of official Analytical Chemists, Washington, DC; 1990.

[25] Hasson K. The effect of frying time of falafels on the quality changes of cotton seeds oil used in local market. Damascus University Journal for Agricultural Sciences 2012; 28 (2): 349-360

[26] Melton S, Jafar LS, Sykes D, Trigiano MK. Review of stability measurements for frying oils and fried food flavour. Journal American Oil Chemical Society 1994; 71: 1301-1308.

[27] Yunsheng L. Quality changes in chicken nuggets fried in oils with different degrees of hydrogenation. MSc Thesis, McGill University Montreal, Quebec: Canada: 2005.

[28] Farag RS, Hewedi FM, Abu-Raiia SH, El-Barbty GA. Comparative study on the deterioration of oils by microwave and conventional heating. Journal of Food Protection 1992 ;55 (9): 722-727.

[29] Bangash FK, Khattak H. Effect of deep fat frying on physico-chemical properties of silybum marianum and sunflower seed oils. Journal of the Chemical Society of Pakistan 2006; 28: 2

[30] Farhoosh R, Moosavi SMR. Evaluating the performance of peroxide and conjugated diene values in monitoring quality of used frying oils. Journal of Agricultural Science and Technology 2009; 11: 173179.

[31] Yan HC. A comparative study of analytical methods for evaluation of soybean oil quality. Journal of the American Oil Chemists' Society 1991; 68 (6): 379384.

[32] Tseng YC, Moreira R, Sun X. Total frying use time effects on soybean oil deterioration and on tortilla chip quality. International Journal of Food Science \& Technology 1996; 31: 287-294.

[33] Smouse T. The frying properties of vegetable oils. CENTO Scientific program panel on regional problems of edible oils and fats, Lahore; Pakistan: 1975.

[34] Varela SL, Sanchez-Muniz FJ, Cuesta C. Decreased food efficiency ratio, growth retardation and changes in liver fatty acid composition in rats consuming thermally oxidized and polymerized sunflower oil used for frying. Food and Chemical ToxicologyJournal 1995; 33: 181-189.

[35] Abdel-Rahman, AHY. Effect of deep frying on cotton seed oil, sunflower seed oil, soybean oil and corn oil. RISG Rivista Italiana Sostanze Grasse 1984; 62 (10): 573 - 574 
[36] Orthoefer FT, Cooper DS. Evaluation of used frying oil. In Perkins, Erickson, M.D. (Eds.) Deep Frying.; Chemistry, Nutrition, and Practical Application. Journal of the American Oil Chemists' Society 1996: 285-296.
[37] Suleiman, AE-RM, El-Makhzangy A, Ramadan MF. Antiradical performance and physicochemical characteristics of vegetable oils upon frying of Fren chfries: Prelimiary Comparative. Electronic Journal of Environmental, Agricultural and Food Chemistry. 2006; 5 (4):1429-1441 